\title{
Transcriptome analysis of embryonic and adult sensory axons reveals changes in mRNA repertoire localization
}

\author{
LAURA F. GUMY, ${ }^{1,7}$ GILES S.H. YEO, ${ }^{2,7}$ YI-CHUN LORAINE TUNG, ${ }^{2}$ KRISHNA H. ZIVRAJ, ${ }^{3}$ DIANNA WILLIS, ${ }^{4}$

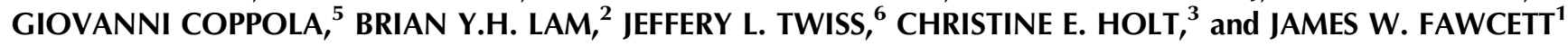 \\ ${ }^{1}$ Centre for Brain Repair, University of Cambridge, Forvie Site, Cambridge CB2 OPY, United Kingdom \\ ${ }^{2}$ University of Cambridge Metabolic Research Labs, Institute of Metabolic Science, Addenbrooke's Hospital, Cambridge CB2 0QQ, \\ United Kingdom \\ ${ }^{3}$ Department of Physiology, Development and Neuroscience, University of Cambridge, Cambridge CB2 3DY, United Kingdom \\ ${ }^{4}$ Burke-Cornell Medical Research Institute, White Plains, New York 10605, USA \\ ${ }^{5}$ Program in Neurogenetics, Department of Neurology, David Geffen School of Medicine, University of California, Los Angeles, \\ California 90095, USA \\ ${ }^{6}$ Department of Biology, Drexel University, Philadelphia, Pennsylvania 19401, USA
}

\begin{abstract}
mRNAs are transported, localized, and translated in axons of sensory neurons. However, little is known about the full repertoire of transcripts present in embryonic and adult sensory axons and how this pool of mRNAs dynamically changes during development. Here, we used a compartmentalized chamber to isolate mRNA from pure embryonic and adult sensory axons devoid of non-neuronal or cell body contamination. Genome-wide microarray analysis reveals that a previously unappreciated number of transcripts are localized in sensory axons and that this repertoire changes during development toward adulthood. Embryonic axons are enriched in transcripts encoding cytoskeletal-related proteins with a role in axonal outgrowth. Surprisingly, adult axons are enriched in mRNAs encoding immune molecules with a role in nociception. Additionally, we show Tubulin-beta3 (Tubb3) mRNA is present only in embryonic axons, with Tubb3 locally synthesized in axons of embryonic, but not adult neurons where it is transported, thus validating our experimental approach. In summary, we provide the first complete catalog of embryonic and adult sensory axonal mRNAs. In addition we show that this pool of axonal mRNAs dynamically changes during development. These data provide an important resource for studies on the role of local protein synthesis in axon regeneration and nociception during neuronal development.
\end{abstract}

Keywords: axon regeneration; local protein synthesis; microarray; dorsal root ganglion neurons; pain; development; mRNA

\section{INTRODUCTION}

Recent studies have shown mechanisms by which mRNAs are transported, localized, and locally translated in mammalian and invertebrate dendrites and axons, playing an important role in neuronal function (Verma et al. 2005; Willis et al. 2005; Leung et al. 2006; Taylor et al. 2009; Andreassi et al. 2010). Although common features in the localization of mRNAs are emerging, these data are heterogeneous because of the use of different types of neurons, with different

\footnotetext{
${ }^{7}$ These authors contributed equally to this work.

Reprint requests to: James W. Fawcett, Centre for Brain Repair, University of Cambridge, Forvie Site, Robinson Way, Cambridge CB2 OPY, U.K.; e-mail: jf108@cam.ac.uk; fax: (44) 1223-331174; or Giles S.H. Yeo, University of Cambridge Metabolic Research Labs, Level 4, Institute of Metabolic Science, Box 289, Addenbrooke's Hospital, Cambridge CB2 0QQ, UK; e-mail: gshy2@cam.ac.uk; fax: (44)1223-330598.

Article published online ahead of print. Article and publication date are at http://www.rnajournal.org/cgi/doi/10.1261/rna.2386111.
}

levels of in vitro maturation and of diverse ages making it difficult to systematically study the mechanism of axonal transport and localization in response to intrinsic and/or extrinsic stimuli. One intrinsic characteristic of sensory dorsal root ganglion (DRG) neurons is that younger axons possess a higher capacity to regenerate after injury than older axons, which also correlates with higher levels of translational machinery (Chierzi et al. 2005; Verma et al. 2005). However, little is known about the composition of the pool of transcripts present in these axons during development. For these reasons, we used compartmentalized chambers allowing us to isolate pure axonal mRNAs from embryonic and adult DRG axons devoid of any cell body or non-neuronal cell contamination (Vogelaar et al. 2009). We then used genomewide microarray expression analysis to investigate the full repertoire of mRNAs transported and localized to axons at different ages. Our data show that regenerating axons from embryonic and adult DRG neurons contain similar numbers, 
but very different populations of mRNAs encoding proteins of diverse functions, implying that ongoing changes occur in axonal transport and localization of mRNAs during ageing and development toward adulthood. Surprisingly, adult axons are enriched in mRNAs encoding immune molecules with a role in nociception. Finally, we show that Tubulin-beta 3 (Tubb3) mRNA is localized only in embryonic axons, with Tubb3 protein being locally synthesized in axons of embryonic neurons, while delivery of Tubb3 protein to the axons and growth cones of adult neurons occurs by axonal transport, validating our experimental approach. These data provide an important resource for studies on the role of local protein synthesis in neuronal and axon function.

\section{RESULTS}

\section{Isolation of pure axonal mRNA from embryonic and adult DRG axons}

A compartmentalized-chamber culture method was utilized, which allowed the extraction of axonal material from embryonic and adult rat DRG explants cultured under serum-free conditions (Vogelaar et al. 2009). Briefly, DRG explants were placed in a line next to parallel scratches to direct axonal growth. After $1 \mathrm{~d}$ in culture a silicon elastomer barrier was placed next to the DRG explants. Embryonic and adult DRG axons grew under the barrier for $1-2 \mathrm{~cm}$. Mitomycin $\mathrm{C}$ was added to the axonal compartment to block survival of any fibroblasts and Schwann cells that managed to trespass the barrier (Vogelaar et al. 2009). This methodology enabled the isolation of RNA from pure embryonic or adult axons devoid of cell bodies and non-neuronal cells. To ensure there was no cell contamination, prior to amplification and hybridization of the RNA onto the gene chip, the extracted RNA samples were screened for the presence of Schwann cell myelin protein P0 and cell body DNA polymerase beta by qPCR (Supplemental Fig. S1). We previously showed that we were able to detect as little as $10^{-1}$ cells per RNA sample and we were therefore able to discard cultures with cytoplasmic contamination of one cell or less (Vogelaar et al. 2009). Uncontaminated samples were hybridized onto the rat whole genome oligonucleotide arrays (Affymetrix).

\section{Microarray analysis of embryonic and adult DRG axonal mRNAs}

The microarray data obtained were analyzed maintaining high stringency in order to reduce the number of false positives, as previously reported (Tung et al. 2008). Three different analysis algorithms were used: (1) GeneChip Operating Software (GCOS), (2) Robust Multiarray Average (RMA), and (3) a variant of RMA that uses probe sequence coupled with GC-content background correction (GC-RMA). Only genes whose expression patterns in each of the three analyses were identical were taken forward for further study. Using this strategy, we found that similar numbers of axonal mRNAs were present in regenerating axons of different developmental stages, with 2627 transcripts localized to embryonic axons and 2924 transcripts localized to adult axons (Fig. 1; for full gene lists see Supplemental Lists S1 and S2).

\section{The repertoire of axonal mRNAs changes between embryonic and adult DRG neurons}

To identify how the localization of mRNAs changed during development we compared the axonal mRNA repertoire of embryonic and adult axons. This comparison showed that embryonic and adult axons shared 1445 transcripts of which 1272 transcripts were relatively enriched in embryonic axons, while 173 transcripts were relatively enriched in adult axons (minimum 1.2-fold enrichment). In addition, 1182 mRNAs were detected exclusively in embryonic axons, while 1479 were only found in adult axons (Fig. 2; Supplemental List S3A-C). Therefore, these results show that regenerating embryonic and adult DRG sensory axons contain different populations of mRNAs that change during ageing.

\section{Both embryonic and adult DRG axons are enriched in protein synthesis, mitochondrial, and neurite development-related mRNAs}

We next analyzed the embryonic and adult axonal data sets using a pathway analysis package (Ingenuity Pathway Analysis), which detects groups of functionally related annotated genes. The pathway analysis revealed that embryonic and adult axons were both enriched in mRNAs that belonged to the protein synthesis, mitochondrial, and neurological disease categories (Table 1A-D; Supplemental List S4A-D).

Within the protein synthesis category we detected 44 embryonic and 35 adult transcripts encoding for ribosomal proteins out of the 80 that have been described in the rat genome (Wool et al. 1995). Other mRNAs related to protein translation that were detected include the eukaryotic elongation factor 2 (Eef2), the eukaryotic translation initiation
A)

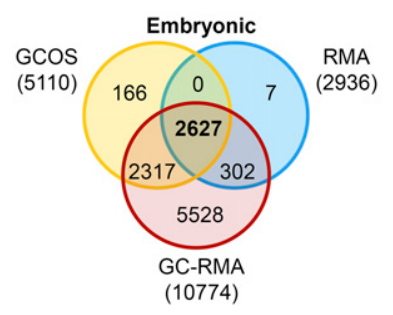

B)

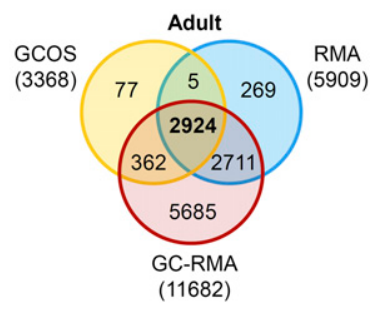

FIGURE 1. Venn diagrams comparing the three different analyses: GCOS, GC-RMA, and RMA in embryonic and adult DRG axons. (A) The 2627 genes present in embryonic axons, (B) the 2924 genes present in adult axons. Numbers in parentheses indicate the number of genes as determined by either the GCOS, RMA, or GCRMA algorithms (see Materials and Methods). 
factor 2, subunit 1 alpha (Eif2S1), and the eukaryotic translation initiation factor $2 \mathrm{~A}($ Eif $2 A)$. The mitochondrial-related mRNAs that were enriched in both the embryonic and adult axons were encoded by both nuclear and mitochondrial genes. These included mRNAs encoding NADH dehydrogenase components, cytochrome c oxidase subunits, mitochondrial, and vacuolar H+ ATP synthase subunits. Both embryonic and adult axons also appeared to be enriched in mRNAs involved in neurite development and growth (Neurological disease category) such as beta-actin (Actnb), stathmin (Stmn1), dihydropyrimidinase-like 2 (Dpysl2, also named Crmp2), reticulon 1 and 4 (Rtn1, Rtn4), tubulin-beta 2 (Tubb2c), and the small GTPases Cell division control protein 42 homolog (Cdc42) and Ras-related C3 botulinum toxin substrate 1(Rac1) (Table 2).

These data show that axons isolated from embryonic and adult rat DRG neurons are enriched in protein synthesis, mitochondrial, and neurite growth-related mRNAs that appear to be common critical elements found in other types of axons (Chun et al. 1995, 1997; Bassell et al. 1998; Eng et al. 1999; Zheng et al. 2001; Gioio et al. 2004; Willis et al. 2005, 2007; Wu et al. 2005; Leung et al. 2006; Aschrafi et al. 2008, 2010; Taylor et al. 2009; Andreassi et al. 2010).

\section{Cytoskeletal and transport-related mRNAs are present only in embryonic axons}

One characteristic that differentiates embryonic from adult DRG axons is that embryonic axons intrinsically regenerate more successfully than adult ones (Chierzi et al. 2005; Verma et al. 2005). We found that embryonic axons exclusively localized transcripts belonging to the "cellular assembly and organization category" (Table 3A; Supplemental List S5). These mRNAs could be further subdivided into two smaller subsets of cellular function categories, namely (1) cytoskeletal-related mRNAs and (2) transport of vesicles/traffickingrelated mRNAs (Table 3B). Examples of cytoskeletal mRNAs were several "core" cytoskeletal components. These included

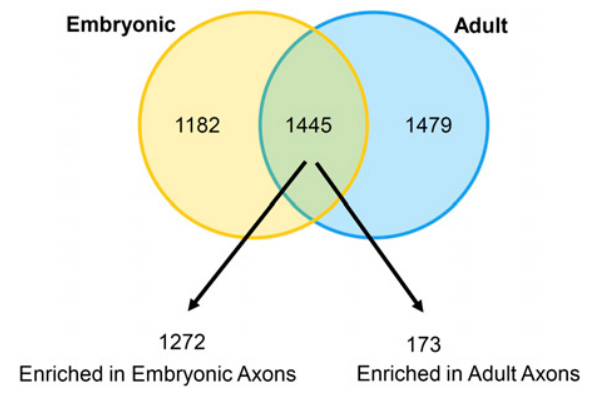

FIGURE 2. Embryonic and adult sensory axons contain different repertoires of mRNAs. Venn diagram showing overlapping (1445) and uniquely localized mRNAs in embryonic (1182) and adult (1479) DRG axons. Of the overlapping mRNAs, 1272 were upregulated (enriched) in embryonic axons while 173 were enriched in adult ones.
TABLE 1. Pathway analyses of transcripts identified in DRG axons

(A) Molecular and cellular functions represented in embryonic DRG axons

\begin{tabular}{lc}
\hline Category & $P$-value \\
\hline Neurological disease & $1.38 \mathrm{E}-17$ \\
Protein synthesis & $2.98 \mathrm{E}-15$ \\
Genetic disorder & $6.63 \mathrm{E}-15$ \\
Post-translational modification & $4.90 \mathrm{E}-10$ \\
Protein folding & $4.90 \mathrm{E}-10$ \\
Cancer & $2.91 \mathrm{E}-08$ \\
Cell death & $2.91 \mathrm{E}-08$ \\
Gastrointestinal disease & $8.72 \mathrm{E}-06$ \\
Cellular assembly and organization & $8.81 \mathrm{E}-06$ \\
Connective tissue disorders & $1.14 \mathrm{E}-05$ \\
Respiratory disease & $1.41 \mathrm{E}-05$ \\
Reproductive system disease & $2.36 \mathrm{E}-05$ \\
Cellular growth and proliferation & $2.38 \mathrm{E}-05$ \\
RNA post-transcriptional modification & $3.60 \mathrm{E}-05$ \\
Energy production & $8.86 \mathrm{E}-05$ \\
Nucleic acid metabolism & $8.86 \mathrm{E}-05$ \\
Small molecule biochemistry & $8.86 \mathrm{E}-05$ \\
Protein degradation & $1.29 \mathrm{E}-04$ \\
Molecular transport & $1.97 \mathrm{E}-04$ \\
Protein trafficking & $1.97 \mathrm{E}-04$ \\
\hline
\end{tabular}

(B) Molecular and cellular functions represented in adult DRG axons

\begin{tabular}{lc}
\hline Category & $P$-value \\
\hline Protein synthesis & $1.95 \mathrm{E}-21$ \\
Cell death & $4.26 \mathrm{E}-12$ \\
Cancer & $1.16 \mathrm{E}-11$ \\
Gastrointestinal disease & $1.16 \mathrm{E}-11$ \\
Genetic disorder & $2.09 \mathrm{E}-10$ \\
Neurological disease & $2.09 \mathrm{E}-10$ \\
Small molecule biochemistry & $3.51 \mathrm{E}-09$ \\
Cellular growth and proliferation & $1.08 \mathrm{E}-08$ \\
Connective tissue disorders & $2.09 \mathrm{E}-08$ \\
Inflammatory disease & $2.09 \mathrm{E}-08$ \\
Skeletal and muscular disorders & $2.09 \mathrm{E}-08$ \\
Immunological disease & $2.64 \mathrm{E}-08$ \\
Post-translational modification & $2.21 \mathrm{E}-07$ \\
Protein folding & $2.21 \mathrm{E}-07$ \\
Hematological disease & $3.21 \mathrm{E}-07$ \\
Respiratory disease & $3.21 \mathrm{E}-07$ \\
Protein degradation & $9.15 \mathrm{E}-07$ \\
Cellular movement & $2.00 \mathrm{E}-06$ \\
Protein trafficking & $5.93 \mathrm{E}-06$ \\
Lipid metabolism & $1.05 \mathrm{E}-05$ \\
\hline C) Molecular and cellular functions shared by embryonic and \\
adult DRG axons & \\
\hline Category & $P$-value \\
\hline Protein synthesis & $6.65 \mathrm{E}-25$ \\
Genetic disorder & $4.83 \mathrm{E}-11$ \\
Neurological disease & $4.83 \mathrm{E}-11$ \\
Cancer & $4.92 \mathrm{E}-08$ \\
Gastrointestinal disease & $4.92 \mathrm{E}-08$ \\
Cell death & $1.74 \mathrm{E}-07$ \\
Connective tissue disorders & $1.11 \mathrm{E}-06$ \\
\hline & $($ continued \\
& \\
& \\
&
\end{tabular}


TABLE 1. Continued

\begin{tabular}{lc}
\hline Category & $P$-value \\
\hline Cellular development & $1.79 \mathrm{E}-06$ \\
Cellular growth and proliferation & $1.79 \mathrm{E}-06$ \\
Connective tissue development and function & $1.79 \mathrm{E}-06$ \\
Cellular assembly and organization & $1.00 \mathrm{E}-05$ \\
Post-translational modification & $1.80 \mathrm{E}-05$ \\
Protein folding & $1.80 \mathrm{E}-05$ \\
Infection mechanism & $2.00 \mathrm{E}-05$ \\
Respiratory disease & $3.11 \mathrm{E}-05$ \\
RNA post-transcriptional modification & $4.88 \mathrm{E}-05$ \\
Protein trafficking & $9.28 \mathrm{E}-05$ \\
Energy production & $1.01 \mathrm{E}-04$ \\
Nucleic acid metabolism & $1.01 \mathrm{E}-04$ \\
Small molecule biochemistry & $1.01 \mathrm{E}-04$ \\
\hline (D) Pathways represented in embryonic DRG axons & \\
\hline Pathways & $P$-value \\
\hline Oxidative phosphorylation & $2.51 \mathrm{E}-31$ \\
Mitochondrial dysfunction & $3.98 \mathrm{E}-18$ \\
Ubiquinone biosynthesis & $7.94 \mathrm{E}-16$ \\
Cardiac $\beta$-adrenergic signaling & $4.17 \mathrm{E}-06$ \\
Protein ubiquitination pathway & $5.01 \mathrm{E}-06$ \\
\hline (E) Pathways represented in adult DRG axons & \\
\hline Pathways & \\
\hline Oxidative phosphorylation & $3.16 \mathrm{E}-17$ \\
Mitochondrial dysfunction & $1.26 \mathrm{E}-12$ \\
fMLP signaling in neutrophils & $2.51 \mathrm{E}-06$ \\
Ubiquinone biosynthesis & $3.24 \mathrm{E}-06$ \\
NRF2-mediated oxidative stress response & $5.13 \mathrm{E}-06$ \\
\hline & \\
&
\end{tabular}

transcripts for isoforms of Tubulin (i.e., Tubb3), several microtubule associated proteins (i.e., Map1B), microtubule stabilizing proteins (i.e., Clasp2), and regulators of actin dynamics (i.e., Cfl1, $P f n 2, D b n 1$ ), several of which have also been reported in different axon types including axons from other species (Chun et al. 1997; Gioio et al. 2004; Willis et al. 2005; Taylor et al. 2009). Within the transport of vesicles category we detected mRNAs encoding anterograde and retrograde microtubule associated motor proteins (i.e., Kif5A, Dctn2) (Hirokawa et al. 2009). All the mRNAs encoding motor proteins that were identified in this study were exclusively restricted to embryonic axons and were undetectable in adult ones. We also detected several components of the adaptor-related protein complex (i.e., AP3S1, AP2A, $A P 1 S 1, A P 4 S 1)$ that function as vesicle coat components in different membrane traffic pathways (Hirst et al. 1999). In addition, another group of mRNAs that appeared to localize exclusively to embryonic axons were members of the synaptotagmin family (i.e., Syt1, Syt4) that are integral membrane proteins of synaptic vesicles involved in vesicular trafficking and exocytosis and mediate $\mathrm{Ca}^{2+}$-triggered neurotransmitter release (Fernandez-Chacon et al. 2001).

\section{Core cell cycle mRNAs are exclusively enriched in embryonic axons}

More evidence showed that embryonic axons were enriched in transcripts involved in axonal growth. Our findings revealed that these axons contained mRNAs encoding core cell cycle proteins with alternative functions in axonal elongation and morphogenesis (Table 4; Frank and Tsai 2009). Examples of these mRNAs included $p 27 / k i p 1$ (CDKN1B) and $p 57 /$ kip2 (CDKN1C), which belong to the family of tumor suppressors Cip/Kip that negatively regulate the cell cycle but have been involved in regulating the cytoskeleton in migrating neurons (Yokoo et al. 2003; Kawauchi et al. 2006; Itoh et al. 2007). We also detected Cyclin I and Cyclin D2 (CCNI, CCND2) and members of the anaphase promoting complex (ANAPC4 and ANAPC11) that traditionally were known to degrade proteins during mitosis, but have recently been suggested to be involved in dendrite morphogenesis, axon growth, and synaptic plasticity (Frank and Tsai 2009). In the embryonic axonal compartment of our study we also identified transcripts (Cul7, Mdm2) encoding modulators of the transcription factor p53.

Altogether these findings reveal that, in contrast to adult axons, embryonic axons appear to specifically localize mRNAs that encode proteins involved in several aspects of axonal maintenance and growth.

\section{Inflammatory and immune response elements are present only in adult axons}

In the adult axon data set we found 1479 mRNAs that were not present in embryonic axons. Many of these mRNAs belonged to numerous canonical inflammation and immune-related categories (Table 5A). To identify their potential function in the axons we analyzed the transcripts present within the antigen presentation and immune and inflammatory response categories (Supplemental List S6A,B). When the genes were examined in this manner they could be subdivided into a smaller subset of ontologies, most notably

TABLE 2. List of neurite development and growth-related molecules enriched in both embryonic and adult axons

\begin{tabular}{ll}
\hline Actb & Actin, beta \\
Tubb2 & Tubulin-beta 2 \\
Dpysl2 & Dihydropyrimidinase-like 2 \\
Stmn1 & Stathmin 1 \\
Stmn2 & Stathmin 2 \\
Rtn1 & Reticulon 1 \\
Rtn4 & Reticulon 4 \\
Cdc42 & Cell division control protein 42 homolog \\
Rac1 & Ras-related C3 botulinum toxin substrate 1 \\
Alcam & Activated leukocyte cell adhesion molecules \\
Nrdg2 & N-myc downstream regulated gene 2 \\
S100A6 & Calcyclin \\
\hline
\end{tabular}


TABLE 3. List of functional categories enriched in embryonic DRG axons

(A) Molecular and cellular functions enriched in embryonic DRG axons

\begin{tabular}{lc}
\hline Category & $P$-value \\
\hline Cellular assembly and organization & $4.51 \mathrm{E}-07$ \\
Neurological disease & $7.79 \mathrm{E}-07$ \\
Genetic disorder & $3.43 \mathrm{E}-06$ \\
Cellular growth and proliferation & $7.95 \mathrm{E}-06$ \\
Protein degradation & $1.55 \mathrm{E}-05$ \\
Protein synthesis & $1.55 \mathrm{E}-05$ \\
RNA post-transcriptional modification & $2.74 \mathrm{E}-05$ \\
Molecular transport & $3.33 \mathrm{E}-05$ \\
Small molecule biochemistry & $3.33 \mathrm{E}-05$ \\
Cell morphology & $8.33 \mathrm{E}-05$ \\
Cellular function and maintenance & $1.34 \mathrm{E}-04$ \\
Cellular movement & $1.34 \mathrm{E}-04$ \\
Nervous system development and function & $1.34 \mathrm{E}-04$ \\
Cellular compromise & $3.05 \mathrm{E}-04$ \\
Gene expression & $3.92 \mathrm{E}-04$ \\
Protein trafficking & $8.34 \mathrm{E}-04$ \\
Post-translational modification & $8.52 \mathrm{E}-04$ \\
Protein folding & $8.52 \mathrm{E}-04$ \\
Cancer & $9.46 \mathrm{E}-04$ \\
Cell-to-cell signaling and interaction & $9.46 \mathrm{E}-04$ \\
\hline
\end{tabular}

(B) Molecules involved in vesicle and cytoskeletal transport enriched in embryonic axons

Vesicle transport and trafficking

AP2A2

AP1S1

AP3S1

AP1M1

AP4S1

SYTL2

SYT1

SYT4

RAB3A

RAB12

SNAP25

Microtubule binding motor protein

KIF1B

KIF3C

KIF5A

KIF5B

KIF5C

Cytoskeletal proteins

DCTN2

DNM1

MAP1B

LMNA

NEFL

MAPRE1(EB1)

CFL1

TUBB3

DCX

DBN1

MAPT

AVIL

FEZ1

PFN2

ENC1

ACTR1A

CRMP1

TBCE

CLASP2
Adaptor-related protein complex 2, $\alpha 2$ Adaptor-related protein complex $1, \sigma 1$ Adaptor-related protein complex $3, \sigma 1$ Adaptor-related protein complex $1, \mu 1$ Adaptor-related protein complex $4, \sigma 1$ Synaptotagmin-like 2

Synaptotagmin I

Synaptotagmin IV

Rab3a, member ras oncogene family Rab12, member ras oncogene family Synaptosomal-associated protein 25

Kinesin family member $1 \mathrm{~b}$ Kinesin family member $3 \mathrm{c}$ Kinesin family member 5 a Kinesin family member $5 b$ Kinesin family member $5 \mathrm{c}$

Dynactin 2

Dynamin 1

Microtubule associated protein $1 \mathrm{~b}$ Lamin A

Microtubule-associated protein RP/EB 1

Cofilin 1

Tubulin beta 3

Doublecortin

Drebrin1

Microtubule-associated protein Tau Advillin

Fasciculation and elongation protein $\zeta 1$ Profilin 2

Ectodermal-neural cortex

Arp1 actin-related protein 1 homolog A Collapsin response mediator proein 1

Tubulin specific chaperone $\mathrm{E}$

Cytoplasmic linker associated protein 2
Neurofilament light chain
(1) cytokine-cytokine receptor interactions, (2) Toll-like receptor signaling pathways, and (3) immune response/ antigen presentation and processing $(\mathrm{Ta}$ ble $5 \mathrm{~B}$ ), all of which play a role at different stages in the genesis and maintenance of chronic and neuropathic pain. This finding is very important given recent evidence showing that local axonal translation is required for the regulation of nociception (Jimenez-Diaz et al. 2008; Geranton et al. 2009; Price and Geranton 2009). However, until now, no evidence has shown or suggested which mRNAs might be translated and this data provide the first evidence for the identity of these mRNAs.

\section{Preinjured DRG axons are enriched in immune-related mRNAs}

Injury to peripheral nerves has many consequences, including acute chronic and neuropathic pain syndromes, and also the conditioning effect that increases the vigor of axon regeneration. In both cases, the up-regulation of proinflammatory cytokines and other immune molecules is involved (Richardson and $\mathrm{Lu}$ 1994; Ji and Strichartz 2004; White et al. 2007). It is therefore of considerable interest that we have found many inflammation and immune-related mRNAs localized in adult axons. These mRNAs came from axons growing from DRG neurons whose axons had not been previously injured (regenerating). In order to determine if inflammation and immune-related mRNAs are also present in previously injured nerves, we looked for the presence of the relevant mRNAs in axons growing from DRGs whose axons were injured by in vivo sciatic nerve crush prior to culturing (preinjured), derived from an independent microarray data set. This axonal material from preinjured adult DRG axons was obtained as described by Willis et al. $(2005,2007)$. When the two data sets were compared a core list of 812 common genes was found to overlap between the studies (Supplemental List S7). Analysis of the composition of the core transcripts revealed that these mRNAs belonged to similar categories as the mRNAs present in regenerating adult 
TABLE 4. List of "core" cell cycle molecules with a function in axon growth enriched in embryonic axons

Cell cycle proteins

CCNI Cyclin I

CCND2 Cyclin D2

CDKN1B Cyclin-dependent kinase inhibitor 1B (p27/kip1)

CDKN1C Cyclin-dependent kinase inhibitor 1B (p57/kip2)

Cul7 Cullin 7

MDM2 Murine double munte 2

ANAPC4 Anaphase-promoting complex 4

ANAPC11 Anaphase-promoting complex 11

NDN Necdin homolog

DRG axons (Table 1B), with mRNAs for protein synthesis, mitochondrial, and the cell death categories being the largest categories (Table 6). Critically, as shown in Tables 5B, 6, many of the mRNAs for cytokines, chemokines and other immunerelated molecules are present in both preinjured and regenerating adult axon mRNA sets. These results further support the notion that local protein synthesis might have a role in the genesis and maintenance of chronic and neuropathic pain after injury.

\section{qPCR validation of transcripts present in embryonic and adult DRG axons}

We selected 25 mRNAs to validate the microarray data using qPCR on independent embryonic and adult axonal samples. For qPCR validation, mRNAs spanning several different cellular and molecular categories, such as cell assembly and organization, cell growth and proliferation, protein synthesis and immune response were chosen. It was demonstrated that 24 out of 25 mRNAs corroborated the microarray data following identical patterns of axonal localization (Table 7). For example, within the cellular assembly and organization category, it was corroborated that the mRNAs of tubulin beta 3 (Tubb3) and kinesins (Kif5a and Kif3c) were present in embryonic axons but undetectable in adult samples. Within the immune response category, the mRNA of the cell surface adhesion molecule Integrin Beta2 (Itgb2) was only detected in adult axons validating the microarray result. Other transcripts that appeared as present in both embryonic and adult axons in the microarray data set were confirmed. These included cell growth and proliferation molecules such as cyclin G1 (Ccng1), Histone 2A ( H2A), protein synthesis-related transcripts such as eukaryotic elongation translation factor 2 (Eef2), ribosomal protein SA (Rpsa), and the widely validated transcript of beta-Actin $(A c t n b)$.

\section{The mRNA of Tubb3 is locally translated in embryonic axons}

We next investigated whether one of the differentially expressed mRNAs was locally synthesized. We detected Tubb3
mRNA only in embryonic DRG axons and not in adult axons. Thus, we hypothesized that in embryonic axons Tubb3 protein might be supplied by both local translation and axonal transport from the cell body, while Tubb3 localization in adult axons might be entirely dependent on axonal transport. To verify whether Tubb3 was locally synthesized in embryonic axons we cultured dissociated adult and embryonic DRG neurons in microfluidic chambers that isolate cell body and proximal axons from distal growth cones and axons. The microfluidic chambers have been previously used for isolation of axonal mRNA from cortical neurons and for the compartmentalized culture of DRG neurons allowing liquid separation between the two compartments (Hengst et al. 2009; Taylor et al. 2009). The adult and embryonic DRG neuron cultures extended axons through the microgrooves of the chambers into the adjacent compartment, as described by Hengst and colleagues (2009) and were treated with the protein synthesis inhibitor cycloheximide separately from the cell body. The results showed that, prior to treatment with cycloheximide, embryonic distal axons showed similar Tubb3 immunoreactivity levels to their counterparts in the cell body compartment (Fig. 3). However, treatment with cycloheximide of distal axons significantly decreased by $50 \%$ the immunoreactivity of Tubb3 compared to untreated proximal axons in the cell body compartment (Fig. 3). No changes in intensity levels were observed in proximal axons in the cell body compartment. In adult DRG cultures, cycloheximide treatment of the distal axon or the cell body compartment did not affect axonal Tubb3 (Fig. 3). These results suggest that Tubb3 mRNA is locally translated in embryonic axons, as well as being axonally transported, while adult axons appear to rely entirely on axonal transport for the provision of Tubb3 protein. These results show that axonal localization and translation of a cytoskeletal component in embryonic axons, but not in adult axons, might contribute to differences in axonal growth observed during maturation.

\section{DISCUSSION}

In the current study we examine the axonal transcriptome from the two extremes of development, the embryonic and adult stages, thus allowing us to determine if the repertoires of mRNAs change at different ages.

The absolute numbers of transcripts we report, 2627 in embryonic and 2924 in adult axons, are significantly higher than those previously reported in similar studies (Willis et al. 2005, 2007; Taylor et al. 2009). This discrepancy can be explained by differences in the total number of transcripts actually present on the array (Willis et al. 2005; Taylor et al. 2009). Taking these differences into account, we report that anywhere between $6 \%$ and $10 \%$ of the total number of transcripts are present in vertebrate sensory axons, which is consistent with previous studies (Willis et al. 2005; Taylor et al. 2009). Interestingly, a recent study that utilized sequential analysis of gene expression (SAGE) to identify 
TABLE 5. List of functional categories enriched in adult DRG axons

(A) Molecular and cellular functions enriched in adult DRG axons

\begin{tabular}{lc}
\hline Category & $P$-value \\
\hline Antigen presentation & $5.10 \mathrm{E}-10$ \\
Cell-mediated immune response & $5.10 \mathrm{E}-10$ \\
Humoral immune response & $5.10 \mathrm{E}-10$ \\
Inflammatory response & $5.10 \mathrm{E}-10$ \\
Cancer & $4.66 \mathrm{E}-08$ \\
Cellular movement & $4.66 \mathrm{E}-08$ \\
Cell death & $6.25 \mathrm{E}-08$ \\
Hematological disease & $7.80 \mathrm{E}-08$ \\
Immunological disease & $7.80 \mathrm{E}-08$ \\
Cell-to-cell signaling and interaction & $9.85 \mathrm{E}-08$ \\
Hematological system development \& function & $9.85 \mathrm{E}-08$ \\
Immune cell trafficking & $9.85 \mathrm{E}-08$ \\
Tissue morphology & $1.96 \mathrm{E}-07$ \\
Cell morphology & $3.19 \mathrm{E}-07$ \\
Cellular growth and proliferation & $4.88 \mathrm{E}-07$ \\
Carbohydrate metabolism & $6.43 \mathrm{E}-07$ \\
Connective tissue disorders & $1.22 \mathrm{E}-06$ \\
Inflammatory disease & $1.22 \mathrm{E}-06$ \\
Skeletal and muscular disorders & $1.22 \mathrm{E}-06$ \\
\hline
\end{tabular}

(B) Inflammatory and immune response elements are enriched in adult axons

\begin{tabular}{|c|c|}
\hline \multicolumn{2}{|c|}{ Cytokine-cytokine receptor interaction } \\
\hline $\mathrm{CCL} 2 *$ & Chemokine (C-C motif) ligand 2 \\
\hline CCL3 & Chemokine (C-C motif) ligand 3 \\
\hline $\mathrm{CCL}^{*}$ & Chemokine (C-C motif) ligand 7 \\
\hline CCL13* & Chemokine (C-C motif) ligand 13 \\
\hline CCL22 & Chemokine (C-C motif) ligand 22 \\
\hline $\mathrm{CXCL} 2 *$ & Chemokine (C-X-C motif) ligand 2 \\
\hline $\mathrm{CXCL}^{*}$ & Chemokine (C-X-C motif) ligand 3 \\
\hline PF4* & Platelet factor 4 (Chemokine (c-x-c motif) ligand 4 \\
\hline CXCL13 & Chemokine (C-X-C motif) ligand 13 \\
\hline CXCL16 & Chemokine (C-X-C motif) ligand 16 \\
\hline CXCR4* & Chemokine (C-X-C motif) receptor 4 \\
\hline CSF1R & Colony stimulating dactor 1 receptor \\
\hline IL-18 & Interleukin 18 (interferon gamma inducing factor) \\
\hline IL-10RB & Interleukin 10 receptor, beta \\
\hline IL-13RA1 & Interleukin 13 receptor, alpha 1 \\
\hline IL-10RB & Interleukin 10 receptor, beta \\
\hline IFNGR1* & Interferon gamma receptor 1 \\
\hline IL-2RG & Interleukin 2 receptor, gamma \\
\hline IFITM1 & Interferon-induced trasmembrane protein 1 \\
\hline IK & IK cytokine, down-regulator of HLA II \\
\hline TNFSF13* & Tumor necrosis factor (ligand) superfamily, member 13 \\
\hline TNFRSF14 & Tumor necrosis factor receptor superfamily, member 14 \\
\hline \multicolumn{2}{|c|}{ Toll-like receptor signaling pathway } \\
\hline TLR7 & Toll-like receptor 7 \\
\hline TLR2 & Toll-like receptor 2 \\
\hline Myd88* & Myeloid differentiation primary response gene 88 \\
\hline Stat1 & Signal transducer and activator of transcription 1 \\
\hline LY96 & Lymphocyte antigen 96 \\
\hline SPP1* & Secreted phosphoprotein 1 (Osteopontin) \\
\hline CD14 & CD14 antigen \\
\hline \multicolumn{2}{|c|}{ Immune response/antigen processing and presentation } \\
\hline HLA-DRA & Major histocompatibility comples class II, DR alpha \\
\hline HLA-C & Major histocompatibility comples class I, B \\
\hline HLA-DMB* & Major histocompatibility comples class II, DM beta \\
\hline FCGR2A & Fc fragment of IgG. Low affinity IIA. Receptor (CD32) \\
\hline
\end{tabular}

(continued) axonal mRNAs in developing superior cervical ganglion (SCG) neurons found more than 11,000 tags matching known transcripts (Andreassi et al. 2010)

Our data show that there are broadly similar numbers of transcripts in both embryonic and adult axons, suggesting that the overall capacity for transporting axonal mRNAs does not change during development toward adulthood. There is a large overlap of $\sim 1400$ transcripts that are present in both stages, the most abundant and highly expressed of which correspond to the protein synthesis and mitochondrial categories. These findings are congruent with those reported in previous reports and provide further evidence of a significant role for local translation in mammalian axons (Willis et al. 2005; Taylor et al. 2009; Andreassi et al. 2010). However, when we compared the mRNA content we found that during ageing the axonal localization of these transcripts declined. This was also observed in previous reports (Bassell et al. 1994; Kleiman et al. 1994; Taylor et al. 2009) and corroborated in vivo observations that showed a decline in the expression of protein synthesis machinery during development that correlates with a decrease in the regenerative capacity of axons (Verma et al. 2005).

Both embryonic and adult DRG axons contain a significant number of transcripts that are unique to each developmental stage, with over 1100 transcripts present only in embryonic and over 1400 present only in adult axons, which indicates that changes occur in gene expression, axonal transport, and localization of mRNAs from early development toward adulthood. For example, the highest unique mRNA expressed in adult axons encodes Lysozyme ( $L y z)$, an enzyme that forms part of the innate immune system against bacteria. Lysozyme mRNA was also detected in adult DRG neurons in two previous studies (Costigan et al. 2002; Xiao et al. 2002). The highest unique mRNA expressed in embryonic axons encodes Beta-globin. Beta-globin is a protein that together with alpha-globin makes up Hemoglobin. Interestingly, Hemoglobing protein appears to be expressed and developmentally regulated 
TABLE 5. Continued

(B) Inflammatory and immune response elements are enriched in adult axons

\begin{tabular}{|c|c|}
\hline FCGR2B & Fc fragment of IgG. Low affinity IIB. Receptor (CD32) \\
\hline FCGR1A & Fc fragment of IgG. Low affinity IA. Receptor (CD64) \\
\hline LSP1 & Lymphocyte-specific protein 1 \\
\hline ETS1* & V.ETS erythoblastosis virus E26 oncogene homolog 1 \\
\hline IFI30 & Interferon, gamma-inducible protein 30 \\
\hline CTSC* & Cathepsin C \\
\hline CTSS* & Cathepsin S \\
\hline PTPRJ & Protein tyrosine phosphatase, receptor type J \\
\hline CLEC7A & C-type lectin domain family 7 , member $A$ \\
\hline PTPRC & Protein tyrosine phosphatase, receptor type c \\
\hline HPRT1* & Hypoxanthine phosphoribosyltransferase 1 \\
\hline DLG1* & Discs, large homolog 1 (Drosophila) \\
\hline $\mathrm{FN} 1 *$ & Fibronectin 1 \\
\hline HSP90B1 & Heat shock protein $90 \mathrm{kDA}$ beta \\
\hline APOE* & Apolipoprotein E \\
\hline PTGS2* & Prostaglandin-endoperoxide synthase 2 \\
\hline IGSF6* & Immunoglobulin superfamily, member 6 \\
\hline LILRA6 & $\begin{array}{l}\text { Leukocyte immunoglobulin-like receptor, subfamily } \\
\text { A, member } 6\end{array}$ \\
\hline CD74* & CD74 antigen \\
\hline ITGB2 & $\begin{array}{l}\text { Integrin, beta } 2 \text { (complement component } 3 \text { receptor } \\
3 \text { and } 4 \text { subunit) }\end{array}$ \\
\hline COLEC12 & Collectin subfamily member 12 \\
\hline SEMA4A & $\begin{array}{l}\text { Sema domain, immunoglobulin domain (Ig), } \\
\text { transmembrane domain (TM) and short cytoplasmic } \\
\text { domain, (semaphorin) } 4 \mathrm{~A}\end{array}$ \\
\hline NCF4 & Neutrophil cytosolic factor 4 \\
\hline ANXA11 & Annexin A11 \\
\hline BCL6 & B-cell/Leukemia/lymphoma 6 \\
\hline PSMB8* & Proteosome subunit, beta type 8 \\
\hline C5AR1 & Complement component $5 \mathrm{~A}$ receptor 1 \\
\hline PRKCD* & Protein kinase $\mathrm{C}$, delta \\
\hline $\mathrm{ADA}^{*}$ & Adenosine deaminase \\
\hline BCAP31* & B-cell receptor associated protein 31 \\
\hline CEBPG & CCAAT/enhancer binding protein (C/EBP), gamma \\
\hline SH2B2 & Adaptor protein with pleckstrin homology and src \\
\hline UNC93B1 & UNC-93 homolog B1 \\
\hline ERAP1 & $\begin{array}{l}\text { Type } 1 \text { tumor necrosis factor receptor shedding } \\
\text { aminopeptidase regulator } 1\end{array}$ \\
\hline BCL10* & B-cell leukemia/lymphoma 10 \\
\hline C1QA* & $\begin{array}{l}\text { Complement component } 1, \mathrm{Q} \text { subcomponent, } \\
\text { alpha polypeptide }\end{array}$ \\
\hline UBE2N & Ubiquitin-conjugating enzyme $\mathrm{E} 2 \mathrm{~N}$ \\
\hline СуBВ & Cytochrome B-245, beta polypeptide \\
\hline IER3* & Immediate early response 3 \\
\hline PIK3AP1 & Phosphoinositide-3-kinase adaptor protein 1 \\
\hline CD48* & CD48 antigen \\
\hline HPS1 & Pale ear \\
\hline NFAT5 & Nuclear factor of activated T-cells 5 \\
\hline SIRPA* & $\begin{array}{l}\text { Tyrosine-protein phosphatase non-receptor } \\
\text { type substrate } 1\end{array}$ \\
\hline
\end{tabular}

The asterisk $\left(^{*}\right)$ indicates mRNAs that were also detected in regenerating and preinjured DRG adult axons from independently derived data sets.

in rodent neurons, with higher expression detected in embryonic neurons than in adult ones (Ohyagi et al. 1994; Schelshorn et al. 2009).

We identified that embryonic axons appear to be enriched in mRNAs with a role in axonal guidance and growth. These
mRNAs encode tubulins, microtubule stabilizing proteins, microtubule associated proteins, motor proteins, actin-associated proteins, and cell cycle proteins. Many of these molecules have been involved in stabilizing specific subsets of microtubules on reception of signaling cues (i.e., Clasp2). These proteins are also highly expressed in neurons with actively growing axons and concentrate near the growth cone where they participate in axonal growth (i.e., Map1B). Furthermore, they are up-regulated during axon formation and are necessary for axonal elongation in different neurons (i.e., EB1) (Black et al. 1994; Gonzalez-Billault et al. 2001; Morrison et al. 2002; Galjart 2005; Jimenez-Mateos et al. 2005). Some mRNAs within this functional category were present only in embryonic axons. We detected mRNAs encoding proteins that regulate the dynamics of the actin-rich cytoskeleton and localize to growth cones and axons where they can control neuritogenesis, growth cone steering and the protrusion of filopodia in response to environmental signals. Examples of these molecules are Drebrin (Dbn1) (Sarmiere and Bamburg 2004; Geraldo et al. 2008; Geraldo and Gordon-Weeks 2009), Cofilin 1 (Cfl1) (Sarmiere and Bamburg 2004), and Profilin 2 (Pfn2). Pfn2 was found to regulate the average number of processes per cell in newly plated hippocampal neurons, suggesting that it might play a role in the provision of plasma membrane during spreading (Pilo Boyl et al. 2007). Motor proteins function in the anterograde and retrograde axonal transports of a wide variety of molecules. In this study we found that transcripts for kinesins (kif1a,b, kif3c, kif5a,b,c) and dynactin (Dctn 2,5) were exclusively localized to embryonic axons, suggesting that embryonic neurons might have a greater capacity for axonal transport compared to adult ones.

There is a large amount of literature showing that DRG axons that have been previously lesioned in vivo (preconditioned) grow with greater vigor than DRGs that were not preinjured. This difference in regenerative ability remains so even after the DRGs are transferred to and cultured in vitro. In previous work we found that in vivo preconditioning of DRGs lead 
TABLE 6. List of the 20 most significant molecular and cellular functional categories of the common 812 mRNAs overlapping in regenerating adult DRG axons and preinjured adult DRG axons from an independently derived study

\begin{tabular}{lc}
\hline Category & $P$-value \\
\hline Cell death & $1.44 \mathrm{E}-23$ \\
Protein synthesis & $1.51 \mathrm{E}-18$ \\
Cellular growth and proliferation & $1.37 \mathrm{E}-17$ \\
Neurological disease & $1.65 \mathrm{E}-15$ \\
Cancer & $4.53 \mathrm{E}-14$ \\
Gastrointestinal disease & $1.09 \mathrm{E}-11$ \\
Connective tissue disorders & $2.50 \mathrm{E}-11$ \\
Molecular transport & $4.05 \mathrm{E}-11$ \\
Protein trafficking & $4.05 \mathrm{E}-11$ \\
Hematological disease & $4.77 \mathrm{E}-10$ \\
Immunological disease & $2.88 \mathrm{E}-09$ \\
Cell morphology & $1.21 \mathrm{E}-08$ \\
Post-translational modification & $1.51 \mathrm{E}-08$ \\
Cell cycle & $2.16 \mathrm{E}-08$ \\
Small molecule biochemistry & $2.96 \mathrm{E}-08$ \\
Genetic disorder & $3.09 \mathrm{E}-08$ \\
Skeletal and muscular disorders & $3.09 \mathrm{E}-08$ \\
Cellular assembly and organization & $3.27 \mathrm{E}-08$ \\
Cellular movement & $4.03 \mathrm{E}-08$ \\
Cellular development & $2.91 \mathrm{E}-07$ \\
\hline
\end{tabular}

to an increase in intra-axonal protein synthesis machinery (Verma et al. 2005). Therefore, we sought to compare the mRNA repertoire of adult regenerating axons with an independent-derived data set containing mRNAs from preconditioned adult DRG axons. One of the most unexpected results we observed was that both regenerating and prelesioned adult axons were enriched for mRNAs with a role in inflammation and immunity. When we analyzed these molecules in detail we found that the majority of them have been implicated in the genesis, maintenance, and regulation of chronic pain (Abbadie 2005). For example, chemokines and their receptors are present on adult DRG axons and their interaction appears to strongly excite pain-sensing neurons (Jung et al. 2009). Likewise, Toll-like receptors have been implicated in the onset and persistence of chronic pain. Axonal protein translation has been widely discussed in the context of axonal growth and regeneration; however, only recently it was reported to appear to be a key player in the functioning of a subset of peripheral nociceptors (JimenezDiaz et al. 2008; Geranton et al. 2009; Price and Geranton 2009). So far, few studies have examined the involvement of specific mRNAs in the pathogenesis of neuropathic pain. Preliminary work suggests that the local translation of the calcitonin gene related peptide (also detected in our study) and of the NaV1.8 channel are likely candidates (Thakor et al. 2009; Toth et al. 2009). Our study shows for the first time that a large array of specific mRNAs encoding potential candidates involved in the regulation of nociception are present in adult axons. These mRNAs were also identified in prelesioned DRG axons where the conditioning effect induces robust axonal growth and inflammation. What is the significance of the difference in localization of immune or painrelated mRNAs in adult axons compared to embryonic ones? Interestingly, nerve injury fails to trigger neuropathic pain behavior in young rats and humans (Baron 2006; VegaAvelaira et al. 2009). A reason might be that peripheral nerve injury affects aged and young DRG neurons in different ways. Indeed, a recent study showed that following nerve injury a very high level of transcriptional activity occurs in adult rat DRGs but not in younger ones. Our observations suggest that the different pattern of mRNAs in the axons of DRG neurons of adult and young rats might be instrumental in the postnatal developmental of neuropathic pain (Vega-Avelaira et al. 2009).

The DRGs in our experiments were grown in the presence of NGF to maintain neuronal viability. NGF is released from many inflamed tissues including the damaged skin, so DRG axons in vivo will have frequently been exposed to NGF following painful stimuli, and $45 \%$ of adult DRG neurons express trkA (for review, see Pezet and McMahon 2006). NGF has been shown to lead to the transcriptional up-regulation of pain-related receptors, including TRPV1 and P2X(3) (Ramer et al. 2001; Ji et al. 2002). NGF is a wellrecognized mediator of pain syndromes, causing hyperalgesia with peripheral sensitization of nociceptors and central sensitization of dorsal horn neurons (Shu and Mendell 1999). It is possible that some of the inflammatory genes that we identified in adult DRG axons are up-regulated by NGF, but also interesting, in view of the differences in susceptibility to neuropathic pain, that embryonic axons did not contain these mRNAs despite NGF exposure.

Until recently, the role of immune molecules in neurons remained unappreciated. Our observations do not tell us whether or not these mRNAs are present in the central branch of sensory axons in the spinal cord, and whether they are translated there; this will be an important area for future investigations. The mechanisms of local translation of these molecules in axons could provide candidates for the development of therapeutics for the treatment of neuropathic pain.

Finally, in order to validate that our transcriptomic results are physiologically relevant, we demonstrate that the mRNA of Tubb3 is only present in embryonic axons where it is locally translated into Tubb3 protein. This suggests that during embryonic axonal growth, when growth cones and axons are constantly being exposed to changes in the environment, local synthesis of Tubb3 or other cytoskeletal elements might contribute to rapid changes in the plasticity of the microtubule network that would otherwise be limited if it relied solely on the delivery of cytoskeletal elements by axonal transport.

In summary, we report for the first time the repertoires of mRNAs in embryonic and adult DRG axons and how they change significantly from early development toward adulthood. The ability to locally translate these mRNAs (i.e., 


\begin{tabular}{|c|c|c|c|c|c|}
\hline \multicolumn{6}{|c|}{ qPCR validation corroborates axonal localization of mRNAs from the microarray data set } \\
\hline Category & Gene & $\begin{array}{l}\text { Adult } \\
\text { microarray }\end{array}$ & qPCR & $\begin{array}{l}\text { Embryonic } \\
\text { microarray }\end{array}$ & qPCR \\
\hline \multirow[t]{14}{*}{ Cell assembly and organization } & Actnb & $\mathrm{P}$ & $\mathrm{P}$ & $\mathrm{P}$ & $\mathrm{P}$ \\
\hline & $\mathrm{Nfm}$ & A & A & $\mathrm{P}$ & $\mathrm{P}$ \\
\hline & Scg10 & $\mathrm{P}$ & $\mathrm{P}$ & $\mathrm{P}$ & $\mathrm{P}$ \\
\hline & Tubb3 & A & A & $\mathrm{P}$ & $\mathrm{P}$ \\
\hline & Gap43 & $\mathrm{P}$ & $\mathrm{P}$ & P & P \\
\hline & Kif1A & $\mathrm{P}$ & P & P & P \\
\hline & Kif3A & $A$ & $P$ & $A$ & $P$ \\
\hline & Kif3C & A & A & $\mathrm{P}$ & $P$ \\
\hline & Kif5A & A & A & $P$ & $P$ \\
\hline & CD151 & A & A & $P$ & $P$ \\
\hline & $\mathrm{Cdc} 42$ & $P$ & $P$ & $P$ & $P$ \\
\hline & Rac1 & $P$ & $\mathrm{P}$ & $P$ & $\mathrm{P}$ \\
\hline & Prph & $\mathrm{P}$ & $\mathrm{P}$ & $\mathrm{P}$ & $\mathrm{P}$ \\
\hline & Nrep & A & A & $\mathrm{P}$ & $\mathrm{P}$ \\
\hline \multirow[t]{4}{*}{ Protein synthesis } & Rpsa & $P$ & $\mathrm{P}$ & $P$ & $P$ \\
\hline & Eef2 & $\mathrm{P}$ & $P$ & $\mathrm{P}$ & $P$ \\
\hline & Ubc & $P$ & $P$ & $P$ & $P$ \\
\hline & $\mathrm{H} 2 \mathrm{~A}$ & P & P & P & P \\
\hline \multirow[t]{5}{*}{ Cell growth and proliferation } & Ccng1 & $\mathrm{P}$ & $\mathrm{P}$ & $\mathrm{P}$ & $\mathrm{P}$ \\
\hline & Jun & $P$ & $P$ & $P$ & $P$ \\
\hline & Tctp & $P$ & $P$ & $\mathrm{P}$ & $\mathrm{P}$ \\
\hline & Calm1 & $P$ & $P$ & $\mathrm{P}$ & $\mathrm{P}$ \\
\hline & Fth1 & $P$ & $P$ & $P$ & $P$ \\
\hline \multirow{2}{*}{$\begin{array}{l}\text { Immune-related protein } \\
\text { transport }\end{array}$} & Itgb2 & $P$ & $\mathrm{P}$ & A & A \\
\hline & Ipo13 & A & A & $P$ & $P$ \\
\hline
\end{tabular}

An mRNA was considered positive in axons when (1) it was found in at least three consecutive axon preparations, (2) at least two of the three replicates were positive and reproducible, and (3) the average $\mathrm{Ct}$ value was lower than 34. mRNAs that were positive were designated as $\mathrm{P}$ (present). Target mRNAs that were negative or nondetectable were designated as A (absent). Note that the mRNA of Kif3A was not detected in the microarray analysis but was identified after qPCR validation (italics).
Tubb3) might correlate with their capacity to grow and regenerate after injury. The identification of many immunerelated and pain-related mRNAs in the adult axonal compartment, supports the recent finding that post-injury hyperalgesia may depend on local translation within sensory axons. Finally, many transcripts that overlap between embryonic and adult axons are also common to other types of axons, such as CNS or invertebrate ones, suggesting that they might represent critical elements that are involved in supporting the overall adequate functioning of different types of axons. These data provide an important resource to the scientific community for studies on the role of local protein synthesis in neuronal and axon function.

\section{MATERIALS AND METHODS}

\section{Cell culture for axonal RNA isolation}

\section{Regenerating DRG}

For axonal RNA extraction DRG explants dissected from embryonic (E16) and adult (3-5 mo old) from Sprague Dawley rats were plated into compartmentalized chambers as previously published (Vogelaar et al. 2009). Briefly, the DRG explants were plated in a row on top of scratches made with a Campenot pin rake (Tyler Research Corporation) in nunclon (NUNC) dishes and coated with PDL $(20 \mu \mathrm{g} / \mathrm{mL}$, Sigma) and laminin $(10 \mu \mathrm{g} / \mathrm{mL}$, Sigma) in Dulbecco's modified Eagle's medium (Gibco) containing ITS + (1:100, BD Biosciences), penicillin-streptomyces-fungicide (PSF) (1:100, Sigma), $10 \mu \mathrm{g} / \mathrm{mL}$ of human recombinant insulin (Roche), and $10-100 \mathrm{ng} / \mathrm{mL}$ of NGF. At $1 \mathrm{~d}$ in culture a silicone elastomer insert (Dow Corning) was placed into the dish and $0.5 \mu \mathrm{g} / \mathrm{mL}$ of mitomycin C (MMC, Sigma) was added to the culture medium in order to abolish cell proliferation.

\section{Preinjured DRG}

Axonal RNA from dissociated DRG cultures of preinjured adult Sprague Dawley rats were prepared as previously described (Willis et al. 2005). Briefly, adult rats were injury conditioned by unilateral sciatic nerve crush at midthigh level $7 \mathrm{~d}$ prior to culture (Smith and Skene 1997). Dissociated cultures were prepared from L4-L5 DRGs from the preinjured side and plated into tissue culture inserts containing porous membranes ( $8 \mu \mathrm{m}$ diameter pores; BD Falcon) coated with poly-L-lysine (Sigma) and laminin (Millipore). Axons were isolated after $18 \mathrm{~h}$ in culture by carefully scraping away the cellular contents of the upper membrane surface with a cotton-tipped applicator. The scraped membranes were excised from the insert and then processed for RNA isolation (see below).

\section{RNA isolation and cDNA synthesis}

\section{Regenerating DRG}

Pure axonal RNA was isolated from embryonic (E16) and adult (3-5 mo old) rat DRG axons that had been cultured for 4 $\mathrm{d}$ and that had grown $>1 \mathrm{~cm}$ into the outer compartment of the compartmentalized chambers. The axons were washed three times with cold PBS and were scraped into Trizol reagent (Invitrogen). Total RNA was isolated using the PureLink Micro-to-Midi kit (Invitrogen) following the manufacturer's protocol. An on-column DNase step was performed (Qiagen). Total RNA was eluted in 30 $\mu \mathrm{L}$ of UltraPure DNase/RNase-Free Distilled Water (Invitrogen). For analysis of the RNA prior and after amplification, $10 \mu \mathrm{L}$ of the isolated axonal RNA were reverse-transcribed into cDNA using random hexamer primers (50 ng) and Super Script III according to the manufacturer's instructions (Invitrogen).

\section{Preinjured DRG}

For isolation of RNA from preinjured DRG neurons, the sheared axons were lysed in RNA lysis buffer and RNA isolated using the 
A)

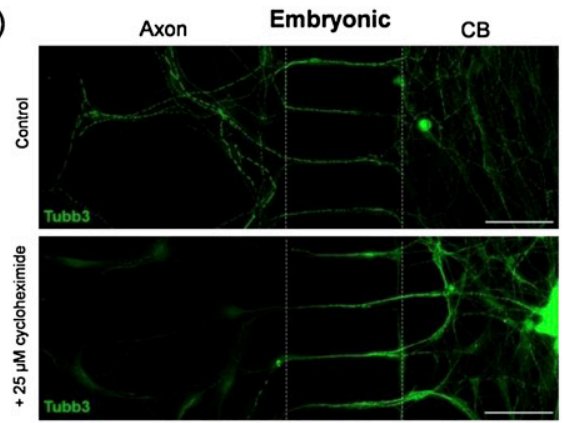

C)

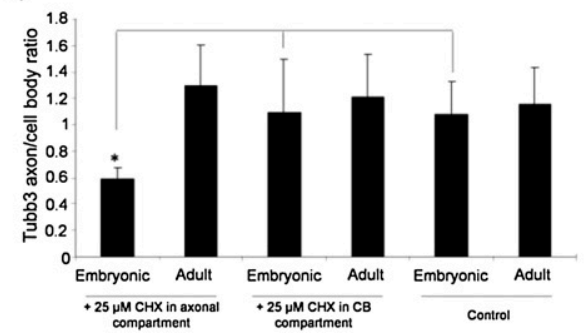

B)
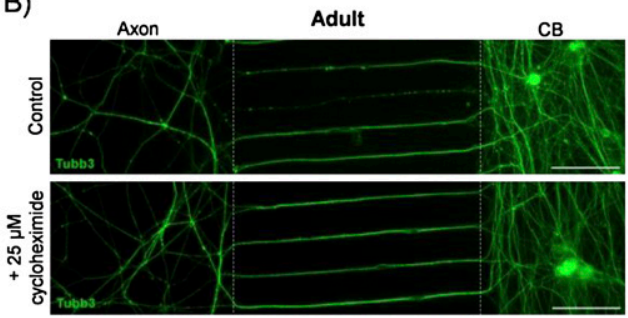

FIGURE 3. Tubb3 is locally translated in embryonic DRG axons. (A) Fluorescent micrograph of Tubb3 immunolabeled embryonic DRG neurons cultured in the compartmentalized microfluidic chamber. Cycloheximide treatment $(25 \mu \mathrm{M})$ for 3 h significantly decreased Tubb3 immunoreactivity in distal axons. CB indicates the cell body compartment. Scale bar $=100 \mu \mathrm{m}$. (B) Fluorescent micrograph of Tubb3 immunolabeled adult DRG neurons cultured in the compartmentalized microfluidic chamber. Cycloheximide treatment $(25 \mu \mathrm{M})$ for $3 \mathrm{~h}$ of distal axons had no effect on Tubb3 levels. CB indicates the cell body compartment. Scale bar $=100 \mu \mathrm{m}$. $(C)$ Quantification of the raw intensity levels of Tubb3 immunofluorescence in cycloheximide-treated and untreated distal axons proximal axons in the cell body compartment. Tubb3 intensity levels in distal axons decreased significantly following cycloheximide treatment compared to untreated controls $\left({ }^{\star} P=0.010\right.$; two-tailed Student's $t$-test). Error bars indicate SD.

RNaqueous-micro kit (Ambion). RNA was quantified by RiboGreen fluorimetry (Molecular Probes). The purity of the axonal preparation was tested by RT-PCR for $\beta$-actin and $\gamma$-actin mRNAs as previously described (Supplemental Fig. 1; Willis et al. 2005).

\section{RNA amplification and microarrays}

Nonamplified RNA samples that were clear of any contaminating RNAs as assessed by qPCR were used for subsequent studies. To minimize bias RNA samples were not pooled and only one individual RNA sample was used per microarray chip. RNA was primed with a T7 promoter oligo-dT primer and reverse transcribed to generate first-strand cDNA, which was used as the template to synthesize second-strand cDNA by DNA polymerase (Two-cycle cDNA Synthesis kit; Affymetrix). The T7 RNA polymerase promoter contained by double-stranded (ds) cDNA molecules was used, by T7 polymerase, to transcribe antisense amplified RNA (aRNA) (MEGAscript T7 kit; Ambion). The aRNA was then randomly primed to make single-stranded cDNA with a $3^{\prime}$ poly(A) tail to serve as the template for second-strand cDNA synthesis primed, as in the first round, with a T7 promoter oligo-dT primer to make ds cDNA containing a T7 promoter site. A second transcription step using T7 polymerase produced the second round of aRNA with biotin-labeled ribonucleotide (GeneChip IVT labeling kit; Affymetrix). The biotin-labeled cRNAs were then fragmented and hybridized to Affymetrix Rat 230.2 oligonucleotide microarrays. The hybridized probe array is stained with streptavidin phyco- erythrin conjugate and scanned on an Affymetrix GeneChip 7G scanner.

\section{Microarray analysis}

Regenerating DRG data set

Each independent experiment comprised of at least five arrays from five biological replicates. Raw image data were converted to CEL and pivot files using Affymetrix GeneChip Operating Software (GCOS). All downstream analysis of microarray data was performed using GeneSpring GX 7.3 (Agilent). The pivot files were used in the GCOS analysis and the CEL files were used for both the robust multiarray average (RMA) (Irizarry et al. 2003) and GC robust multiarray average (GCRMA) analyses and expression values on the chip were normalized to the chip's 50th percentile. Genes were considered "present" with three of five present using GCOS, an intensity $>30$ using RMA or $>10$ using GC-RMA. Only genes that met the above criteria using GCOS, RMA, and GCRMA were taken forward for additional study. If any one of these criteria was not met, then the gene would be considered "not present."

Functional analyses were performed using Ingenuity Pathway Analysis (IPA) (Ingenuity Systems Inc., www.ingenuity.com). The "functions" analysis identified the biological functions and diseases that were most significant to the data set. A right-tailed Fisher's exact test was used to calculate a $P$-value determining the probability that each biological function and disease assigned to that data set is due to chance alone. 
The "pathways" analysis identified canonical pathways from the IPA library that were most significant to the data set. The significance of the association between the data set and the pathway was measured in two ways: (1) A ratio of the number of molecules from the data set that map to the pathway divided by the total number of molecules that map to the canonical pathway is displayed and (2) Fisher's exact test was used to calculate a $P$-value determining the probability that the association between the genes in the data set and the pathway is explained by chance alone.

\section{Preinjured DRG data set}

Total RNA was extracted from axonal preparation from six preinjured neuronal cultures, for a total of six arrays. Total RNA ( $\sim 50 \mathrm{ng}$ ) was amplified, biotin-labeled, and hybridized on Illumina RefSeq-12 Rat Beadchip Expression v. 1.0 arrays, querying the expression of $\sim 24,000$ transcripts, following the manufacturer's recommendations. Slides were scanned using Illumina BeadStation, and the signal was extracted by using Illumina BeadStudio software. Raw data were analyzed by using Bioconductor packages (Gentleman 2005). Quality assessment was performed looking at the interarray Pearson correlation and clustering, based on top variant genes, was used to assess overall data coherence. Log2transformed data were normalized using quantile normalization and used for comparisons.

\section{Real-time quantitative PCR (qPCR)}

qPCR was used for two aims: to assess whether unamplified RNA axonal samples were contaminated with cellular mRNA and to validate the expression of 25 genes from the microarray data set in amplified RNA. qPCR was carried out as reported previously (Vogelaar et al. 2009). Briefly, primers were selected using Premier Biosoft Beacon Designer software. Selection criteria included a Ta between $52^{\circ} \mathrm{C}$ and $60{ }^{\circ} \mathrm{C}$, minimal secondary structures of primers and products $(\Delta G$ values between 0.0 and -2.0$)$, and an overall score greater than 70 . Optimizations were performed using embryonic and adult DRG neuron culture cDNA using iQ SYBRGreen Supermix (Quanta) and the iCycler iQ Thermal Cycler (Biorad). Reactions were run in triplicate, using $5 \mu \mathrm{L}$ of template cDNA. First, a temperature gradient was performed on DRG cDNA in order to find the optimal temperature and primer concentration. Then, standard curves were produced using 10 -fold DRG cDNA dilution series. The qPCR reactions were regarded as optimized when they reached an efficiency between $90 \%$ and $105 \%$ (occasional exceptions were $88 \%-89 \%$ ) with a correlation coefficient greater than 0.994 . Melt curves and sequencing were performed to ensure the absence of primer dimers and the product specificity. The primers used are listed in Supplemental Table S8.

\section{Target gene qPCRs}

In order to identify target genes in axonal samples, $5 \mu \mathrm{L}$ of the axon-only cDNA preparations were subjected to real-time qPCR. Each run also included a positive control cDNA (embryonic or adult whole DRG) and a water control, and reactions were performed in triplicate. Minus reverse transcriptase controls were performed to ensure that there was no DNA contamination. Melt curves were performed in order to confirm that the product from the axon-only cDNA was the same as the product from the diluted DRG cDNA. First, PO myelin protein and DNA polymerase qPCRs were performed on unamplified RNA axonal samples to show that the axons were not contaminated with any cellular mRNA. A target gene was regarded present in axons if (1) it was found in at least three consecutive axon preparations, (2) at least two of the three replicates were positive and reproducible, and (3) the average Ct value was lower than 34 .

\section{Culturing of embryonic and adult dissociated DRG neurons in microfluidic chambers}

For cultures in microfluidic chambers (Xona Microfluidics), embryonic and adult DRG dissociated neurons were isolated and dissociated as previously described (Gumy et al. 2008). The microfluidic chambers were prepared following the manufacturers guidelines and essentially as published by Taylor et al. (2009). Embryonic and adult DRG neurons were resuspended in DMEM containing ITS+, PSF, insulin, and NGF as mentioned above. The suspension of dissociated embryonic or adult DRG neurons was added to one compartment (denominated "cell body compartment"). The cell bodies of neurons attached to the glass substrate coated in PDL and Laminin. After 4-5 d axons grew across to the "distal axonal compartment" through 450 or $150 \mu \mathrm{m}$ grooves. Medium in the distal axonal compartment was removed and new DMEM containing the protein synthesis inhibitor cycloheximide (25 $\mu \mathrm{M}$, Calbiochem) was added to the same compartment for at least $3 \mathrm{~h}$. The height of the medium (containing cycloheximide) in the wells of the distal axon compartment was kept below the height of the medium of the wells in the cell body compartment, allowing separation of liquids between compartments as advised by the manufacturers.

\section{Immunocytochemistry}

Dissociated embryonic and adult DRG neurons cultured in the microfluidic chambers were fixed in $4 \%$ paraformaldehyde for $20 \mathrm{~min}$. The cultures were permeabilized in $0.1 \%$ Triton X-100 in Phosphate buffered saline (PBS) for $15 \mathrm{~min}$ at room temperature (RT) and incubated with the primary antibody diluted in PBS with $10 \%$ normal goat serum for $30 \mathrm{~min}$ at RT. The primary antibody dilution was as follows: monoclonal anti- $\beta$-Tubulin isotype III 1:400 (Sigma). The cultures were washed three times in PBS and incubated for $30 \mathrm{~min}$ at room temperature with the secondary antibody Alexa fluor 488 (1:500, Invitrogen) diluted in PBS. Coverslips were mounted with Fluoromount G mounting medium (Southern Biotech).

\section{Fluorescence imaging and image analysis}

Images were taken using a wide-field epifluorescence Leica microscope and a Leica DFC 350FX camera. All images were taken at the same settings for light and exposure. Images were analyzed by Metamorph image analysis software. Regions around the axons in the distal axonal compartment and in the cell body compartment were drawn using the software, and the average pixel intensity per unit area was calculated. The intensity of the background was similarly measured in areas adjacent to the axons and subtracted from the axon value giving a final intensity value per axon. The final intensity of the axons in the axonal compartment and in the 
cell body compartment per microfluidic chamber was averaged. The average intensity value of the axonal compartment was divided by the average intensity value of the cell body compartment generating a final intensity value that represented the ratio of intensity of Tubb3 in distal axons relative to proximal axons.

\section{Accession number}

Array data are deposited in Gene Expression Omnibus. Accession number: GSE22638.

\section{SUPPLEMENTAL MATERIAL}

Supplemental material can be found at http://www.rnajournal.org.

\section{ACKNOWLEDGMENTS}

This study was supported by a UK Medical Research Council (MRC) Project Grant (J.W.F. and C.E.H.), the EU FP7 project Plasticise (J.W.F.), the MRC Centre for Obesity and Related metabolic Disorders (CORD) (G.S.H.Y. and Y.-C.L.T.), and the EU FP7-HEALTH-2009-241592 EurOCHIP.

Received July 22, 2010; accepted October 21, 2010.

\section{REFERENCES}

Abbadie C. 2005. Chemokines, chemokine receptors and pain. Trends Immunol 26: 529-534.

Andreassi C, Zimmermann C, Mitter R, Fusco S, Devita S, Saiardi A, Riccio A. 2010. An NGF-responsive element targets myo-inositol monophosphatase-1 mRNA to sympathetic neuron axons. Nat Neurosci 13: 291-301.

Aschrafi A, Schwechter AD, Mameza MG, Natera-Naranjo O, Gioio AE, Kaplan BB. 2008. MicroRNA-338 regulates local cytochrome c oxidase IV mRNA levels and oxidative phosphorylation in the axons of sympathetic neurons. J Neurosci 28: 12581-12590.

Aschrafi A, Natera-Naranjo O, Gioio AE, Kaplan BB. 2010. Regulation of axonal trafficking of cytochrome c oxidase IV mRNA. Mol Cell Neurosci 43: 422-430.

Baron R. 2006. Mechanisms of disease: neuropathic pain-a clinical perspective. Nat Clin Pract Neurol 2: 95-106.

Bassell GJ, Singer RH, Kosik KS. 1994. Association of poly(A) mRNA with microtubules in cultured neurons. Neuron 12: 571-582.

Bassell GJ, Zhang H, Byrd AL, Femino AM, Singer RH, Taneja KL, Lifshitz LM, Herman IM, Kosik KS. 1998. Sorting of beta-actin mRNA and protein to neurites and growth cones in culture. J Neurosci 18: 251-265.

Black MM, Slaughter T, Fischer I. 1994. Microtubule-associated protein $1 \mathrm{~b}$ (MAP1b) is concentrated in the distal region of growing axons. J Neurosci 14: 857-870.

Chierzi S, Ratto GM, Verma P, Fawcett JW. 2005. The ability of axons to regenerate their growth cones depends on axonal type and age, and is regulated by calcium, cAMP and ERK. Eur J Neurosci 21: 2051-2062.

Chun JT, Gioio AE, Crispino M, Giuditta A, Kaplan BB. 1995. Characterization of squid enolase mRNA: sequence analysis, tissue distribution, and axonal localization. Neurochem Res 20: 923-930.

Chun JT, Gioio AE, Crispino M, Eyman M, Giuditta A, Kaplan BB. 1997. Molecular cloning and characterization of a novel mRNA present in the squid giant axon. J Neurosci Res 49: 144-153.

Costigan M, Befort K, Karchewski L, Griffin RS, D’Urso D, Allchorne A, Sitarski J, Mannion JW, Pratt RE, Woolf CJ. 2002. Replicate high-density rat genome oligonucleotide microarrays reveal hun- dreds of regulated genes in the dorsal root ganglion after peripheral nerve injury. BMC Neurosci 3: 16. doi: 10.1186/1471-2202-3-16.

Eng H, Lund K, Campenot RB. 1999. Synthesis of beta-tubulin, actin, and other proteins in axons of sympathetic neurons in compartmented cultures. J Neurosci 19: 1-9.

Fernandez-Chacon R, Konigstorfer A, Gerber SH, Garcia J, Matos MF, Stevens CF, Brose N, Rizo J, Rosenmund C, Sudhof TC. 2001. Synaptotagmin I functions as a calcium regulator of release probability. Nature 410: 41-49.

Frank CL, Tsai LH. 2009. Alternative functions of core cell cycle regulators in neuronal migration, neuronal maturation, and synaptic plasticity. Neuron 62: 312-326.

Galjart N. 2005. CLIPs and CLASPs and cellular dynamics. Nat Rev Mol Cell Biol 6: 487-498.

Gentleman R. 2005. Reproducible research: a bioinformatics case study. Stat Appl Genet Mol Biol 4:Article2.

Geraldo S, Gordon-Weeks PR. 2009. Cytoskeletal dynamics in growth-cone steering. J Cell Sci 122: 3595-3604.

Geraldo S, Khanzada UK, Parsons M, Chilton JK, Gordon-Weeks PR. 2008. Targeting of the F-actin-binding protein drebrin by the microtubule plus-tip protein EB3 is required for neuritogenesis. Nat Cell Biol 10: 1181-1189.

Geranton SM, Jimenez-Diaz L, Torsney C, Tochiki KK, Stuart SA, Leith JL, Lumb BM, Hunt SP. 2009. A rapamycin-sensitive signaling pathway is essential for the full expression of persistent pain states. J Neurosci 29: 15017-15027.

Gioio AE, Lavina ZS, Jurkovicova D, Zhang H, Eyman M, Giuditta A, Kaplan BB. 2004. Nerve terminals of squid photoreceptor neurons contain a heterogeneous population of mRNAs and translate a transfected reporter mRNA. Eur J Neurosci 20: 865-872.

Gonzalez-Billault C, Avila J, Caceres A. 2001. Evidence for the role of MAP1B in axon formation. Mol Biol Cell 12: 2087-2098.

Gumy LF, Bampton ET, Tolkovsky AM. 2008. Hyperglycaemia inhibits Schwann cell proliferation and migration and restricts regeneration of axons and Schwann cells from adult murine DRG. Mol Cell Neurosci 37: 298-311.

Hengst U, Deglincerti A, Kim HJ, Jeon NL, Jaffrey SR. 2009. Axonal elongation triggered by stimulus-induced local translation of a polarity complex protein. Nat Cell Biol. 11: 1024-1030.

Hirokawa N, Noda Y, Tanaka Y, Niwa S. 2009. Kinesin superfamily motor proteins and intracellular transport. Nat Rev Mol Cell Biol 10: $682-696$.

Hirst J, Bright NA, Rous B, Robinson MS. 1999. Characterization of a fourth adaptor-related protein complex. Mol Biol Cell 10: 2787-2802.

Irizarry RA, Hobbs B, Collin F, Beazer-Barclay YD, Antonellis KJ, Scherf U, Speed TP. 2003. Exploration, normalization, and summaries of high density oligonucleotide array probe level data. Biostatistics 4: 249-264.

Itoh Y, Masuyama N, Nakayama K, Nakayama KI, Gotoh Y. 2007. The cyclin-dependent kinase inhibitors p57 and p27 regulate neuronal migration in the developing mouse neocortex. J Biol Chem 282: 390-396.

Ji RR, Strichartz G. 2004. Cell signaling and the genesis of neuropathic pain. Sci STKE 2004: reE14. doi: 10.1126/stke.2522004re14.

Ji RR, Samad TA, Jin SX, Schmoll R, Woolf CJ. 2002. p38 MAPK activation by NGF in primary sensory neurons after inflammation increases TRPV1 levels and maintains heat hyperalgesia. Neuron 36: $57-68$.

Jimenez-Diaz L, Geranton SM, Passmore GM, Leith JL, Fisher AS, Berliocchi L, Sivasubramaniam AK, Sheasby A, Lumb BM, Hunt SP. 2008. Local translation in primary afferent fibers regulates nociception. PLoS One 3: e1961. doi: 10.1371/journal.pone.0001961.

Jimenez-Mateos EM, Paglini G, Gonzalez-Billault C, Caceres A, Avila J. 2005. End binding protein-1 (EB1) complements microtubule-associated protein-1B during axonogenesis. J Neurosci Res 80: 350-359.

Jung H, Bhangoo S, Banisadr G, Freitag C, Ren D, White FA, Miller RJ. 2009. Visualization of chemokine receptor activation in transgenic mice reveals peripheral activation of CCR2 receptors in states of neuropathic pain. J Neurosci 29: 8051-8062. 
Kawauchi T, Chihama K, Nabeshima Y, Hoshino M. 2006. Cdk5 phosphorylates and stabilizes p27kip1 contributing to actin organization and cortical neuronal migration. Nat Cell Biol 8: 17-26.

Kleiman R, Banker G, Steward O. 1994. Development of subcellular mRNA compartmentation in hippocampal neurons in culture. J Neurosci 14: 1130-1140.

Leung KM, van Horck FP, Lin AC, Allison R, Standart N, Holt CE. 2006. Asymmetrical beta-actin mRNA translation in growth cones mediates attractive turning to netrin-1. Nat Neurosci 9: 1247-1256.

Morrison EE, Moncur PM, Askham JM. 2002. EB1 identifies sites of microtubule polymerisation during neurite development. Brain Res Mol Brain Res 98: 145-152.

Ohyagi Y, Yamada T, Goto I. 1994. Hemoglobin as a novel protein developmentally regulated in neurons. Brain Res 635: 323-327.

Pezet S, McMahon SB. 2006. Neurotrophins: mediators and modulators of pain. Annu Rev Neurosci 29: 507-538.

Pilo Boyl P, Di Nardo A, Mulle C, Sassoe-Pognetto M, Panzanelli P, Mele A, Kneussel M, Costantini V, Perlas E, Massimi M, et al. 2007. Profilin2 contributes to synaptic vesicle exocytosis, neuronal excitability, and novelty-seeking behavior. EMBO J 26: 2991-3002.

Price TJ, Geranton SM. 2009. Translating nociceptor sensitivity: the role of axonal protein synthesis in nociceptor physiology. Eur J Neurosci 29: 2253-2263.

Ramer MS, Bradbury EJ, McMahon SB. 2001. Nerve growth factor induces $\mathrm{P} 2 \mathrm{X}(3)$ expression in sensory neurons. J Neurochem 77: 864-875.

Richardson PM, Lu X. 1994. Inflammation and axonal regeneration. J Neurol 242: S57-S60.

Sarmiere PD, Bamburg JR. 2004. Regulation of the neuronal actin cytoskeleton by ADF/cofilin. J Neurobiol 58: 103-117.

Schelshorn DW, Schneider A, Kuschinsky W, Weber D, Kruger C, Dittgen T, Burgers HF, Sabouri F, Gassler N, Bach A, et al. 2009. Expression of hemoglobin in rodent neurons. J Cereb Blood Flow Metab 29: 585-595.

Shu XQ, Mendell LM. 1999. Neurotrophins and hyperalgesia. Proc Natl Acad Sci 96: 7693-7696.

Smith DS, Skene JH. 1997. A transcription-dependent switch controls competence of adult neurons for distinct modes of axon growth. J Neurosci 17: 646-658.

Taylor AM, Berchtold NC, Perreau VM, Tu CH, Li Jeon N, Cotman CW. 2009. Axonal mRNA in uninjured and regenerating cortical mammalian axons. J Neurosci 29: 4697-4707.

Thakor DK, Lin A, Matsuka Y, Meyer EM, Ruangsri S, Nishimura I, Spigelman I. 2009. Increased peripheral nerve excitability and local NaV1.8 mRNA up-regulation in painful neuropathy. Mol Pain 5: 14. doi: 10.1186/1744-8069-5-14.
Toth CC, Willis D, Twiss JL, Walsh S, Martinez JA, Liu WQ, Midha R, Zochodne DW. 2009. Locally synthesized calcitonin gene-related peptide has a critical role in peripheral nerve regeneration. J Neuropathol Exp Neurol 68: 326-337.

Tung YC, Ma M, Piper S, Coll A, O’Rahilly S, Yeo GS. 2008. Novel leptin-regulated genes revealed by transcriptional profiling of the hypothalamic paraventricular nucleus. J Neurosci 28: 12419-12426.

Vega-Avelaira D, Geranton SM, Fitzgerald M. 2009. Differential regulation of immune responses and macrophage/neuron interactions in the dorsal root ganglion in young and adult rats following nerve injury. Mol Pain 5: 70. doi: 10.1186/1744-8069-5-70.

Verma P, Chierzi S, Codd AM, Campbell DS, Meyer RL, Holt CE, Fawcett JW. 2005. Axonal protein synthesis and degradation are necessary for efficient growth cone regeneration. J Neurosci 25: 331-342.

Vogelaar CF, Gervasi NM, Gumy LF, Story DJ, Raha-Chowdhury R, Leung KM, Holt CE, Fawcett JW. 2009. Axonal mRNAs: Characterisation and role in the growth and regeneration of dorsal root ganglion axons and growth cones. Mol Cell Neurosci 42: 102-115.

White FA, Jung H, Miller RJ. 2007. Chemokines and the pathophysiology of neuropathic pain. Proc Natl Acad Sci 104: 20151-20158.

Willis D, Li KW, Zheng JQ, Chang JH, Smit A, Kelly T, Merianda TT, Sylvester J, van Minnen J, Twiss JL. 2005. Differential transport and local translation of cytoskeletal, injury-response, and neurodegeneration protein mRNAs in axons. J Neurosci 25: 778-791.

Willis DE, van Niekerk EA, Sasaki Y, Mesngon M, Merianda TT, Williams GG, Kendall M, Smith DS, Bassell GJ, Twiss JL. 2007. Extracellular stimuli specifically regulate localized levels of individual neuronal mRNAs. J Cell Biol 178: 965-980.

Wool IG, Chan YL, Gluck A. 1995. Structure and evolution of mammalian ribosomal proteins. Biochem Cell Biol 73: 933-947.

Wu KY, Hengst U, Cox LJ, Macosko EZ, Jeromin A, Urquhart ER, Jaffrey SR. 2005. Local translation of RhoA regulates growth cone collapse. Nature 436: 1020-1024.

Xiao HS, Huang QH, Zhang FX, Bao L, Lu YJ, Guo C, Yang L, Huang WJ, Fu G, Xu SH, et al. 2002. Identification of gene expression profile of dorsal root ganglion in the rat peripheral axotomy model of neuropathic pain. Proc Natl Acad Sci 99: 8360-8365.

Yokoo T, Toyoshima H, Miura M, Wang Y, Iida KT, Suzuki H, Sone H, Shimano H, Gotoda T, Nishimori S, et al. 2003. p57Kip2 regulates actin dynamics by binding and translocating LIM-kinase 1 to the nucleus. J Biol Chem 278: 52919-52923.

Zheng JQ, Kelly TK, Chang B, Ryazantsev S, Rajasekaran AK, Martin KC, Twiss JL. 2001. A functional role for intra-axonal protein synthesis during axonal regeneration from adult sensory neurons. J Neurosci 21: 9291-9303. 

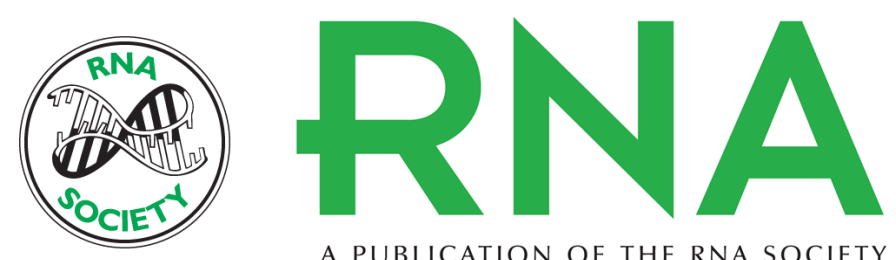

A PUBLICATION OF THE RNA SOCIETY

\section{Transcriptome analysis of embryonic and adult sensory axons reveals changes in mRNA repertoire localization}

Laura F. Gumy, Giles S.H. Yeo, Yi-Chun Loraine Tung, et al.

RNA 2011 17: 85-98 originally published online November 23, 2010

Access the most recent version at doi:10.1261/rna.2386111

\section{Supplemental http://rnajournal.cshlp.org/content/suppl/2010/11/16/rna.2386111.DC1 \\ Material}

References This article cites 61 articles, 22 of which can be accessed free at:

http://rnajournal.cshlp.org/content/17/1/85.full.html\#ref-list-1

\section{License}

Email Alerting Receive free email alerts when new articles cite this article - sign up in the box at the Service top right corner of the article or click here.

To subscribe to $R N A$ go to:

http://rnajournal.cshlp.org/subscriptions 